\title{
THE ECONOMIC SIGNIFICANCE OF THE TOURISM SECTOR IN SEYCHELLES IN THE WAKE OF GLOBAL ECONOMIC CRISIS
}

\section{KATARZYNA PODHORODECKA}

University of Warsaw

Faculty of Geography and Regional Studies

Department of Regional and Political Geography

e-mail: kpodhorodecka@uw.edu.pl

\section{\begin{tabular}{l|l} 
JEL CODES & L83, R1, Z3
\end{tabular} \\ KEYWORDS Seychelles, tourism economy, tropical islands, tourism crisis}

ABSTRACT Since the 1970s, authorities of Seychelles have been focusing on the intensive development of tourism on the archipelago. Many sizable investments have recently been made in the development of the tourism sector. However, the global economic crisis may have contributed to slowing down the development of this sector. The aim of this article is to answer the questions: to what extent is economy of Seychelles dependent on the tourism sector, and is there a relationship between changes in GDP and changes in tourism? The article also aims to assess how the tourism economy of Seychelles reacted to the crisis in tourism prompted by the global economic crisis. The final goal was to investigate how the tourism economy of Seychelles was managed during the global economic crisis. The research methods used in the article were statistical data analysis, the Kendall's tau and Spearman's rank correlation coefficients, analysis of the literature, and an expert interview.

\section{Introduction}

Seychelles is an independent island state located in the Indian Ocean, about 1,200 km from the shores of Madagascar. The islands have been self-governing for more than forty years, having gained independence in 1976. Previously, Seychelles was dependent on Mauritius and functioned as a British colony. Out of 115 Seychelles islands, only one third is inhabited. The islands have a total area of $455 \mathrm{~km}^{2}$ and belong to the group of islands known as SIDS - 'small island developing 
states'. In terms of tourist destinations in their immediate vicinity, they compete with Mauritius and Réunion, and at a further distance with the Maldives. The largest Seychelles archipelagos are the Inner and Outer Islands, while the largest islands are Mahé, Praslin and Silhouette. The islands are located in the humid warm equatorial climate zone (average temperatures are between 24 and $30^{\circ} \mathrm{C}$, rainfall is regular throughout the year with an average of approx. 2,000 mm) (Mydel, Groch, 1998, pp. 325-326). The islands constitute traditional 3S destination type: 'sun, sea and sand', based on the use of natural resources (Seychelles..., 2010, pp. 11-16). The authorities have been intensively developing tourism in this area since the mid-1970s.

The first objective of the article is to answer the question of whether there is a relationship between changes in GDP and changes in tourism in Seychelles. The second objective is to assess the extent to which the economic crisis has contributed to changes in tourism, the amount of employment in tourism, and tourist spending. The third objective of the article is to answer the question of how tourism in Seychelles has been managed and which of the tourist administration's activities were the most effective during the global economic crisis. The following hypotheses were put forward in the article: the global economic crisis (2008-2011) contributed to a decline in tourism, a decline in employment in tourism and a decline in tourist spending. Moreover, on the islands, the activities implemented by the tourist administration consisted mainly in promotion through marketing campaigns on major foreign markets. Methods used in the article are literature analysis (in particular, the analysis of the strategic documents in force in Seychelles), analysis of statistical data from the UNWTO, the WTTC and the World Bank, along with statistical analysis (Kendall's tau and Spearman's rank correlations), and an expert interview conducted with a representative of the Seychelles Ministry of Tourism.

\section{The dependence of small island economies on tourism: the example of Seychelles}

Many authors have focused on the topic of the importance of tourism in island areas (Archer, 1995; Archer, Armstrong, Read, 2000; Bertram, Poirine, 2007; Brigulgio, 1995; Fletcher, 1996; Shareef, Hoti, McAleer, 2008; McElroy, Perri, 2010; Seetanah, 2011) and, more broadly, in the economy of selected countries and regions (Smith, 2000; Balaguer, Cantavella-Jorda, 2002; Sugiyarto, Blake, Sinclair, 2003; Wagner, 1997). A number of studies have analysed the problems of small island economies and their dependence on the tourism sector. These include comparative analyses of islands, as well as analyses of individual case studies. The economic importance of tourism for island areas was analysed by B. Seetanah (2010, pp. 291-308), whose research on 19 tourist islands confirmed that the development of tourism is an important development factor explaining economic growth on islands. A specific economy is particularly noticeable for SIDS 'small island developing states'. The specificity of tourism development in these areas is discussed in the publication 'Tourism in Small Island Developing States' (2014). The economic importance of tourism has been analysed based on the example of the Cayman Islands (Podhorodecka, 2014), and looking at distance as a development factor in island areas (Wites, 2009). Restrictions related to the development of small tropical islands have been described by M. Jędrusik (2014). 
B. Archer and J. Fletcher's paper (1996, pp. 32-47) analysed the economic significance of tourism in Seychelles. The authors conducted a detailed analysis of the impact of tourist spending, employment and profits for public administration, and the balance of payments resulting from the development of tourism in the area. They pointed out that the large diversification of the economic impact of tourists from particular countries was related to the varying size of tourist spending. Although the initial premises of the study were to focus only on a detailed analysis of the effects of tourist spending by country of origin, it emerged that some of the Seychelles source markets have a much larger share in creating added value for the economy of these islands. This was mainly due to the large physical and geographical isolation of the islands. Compared to the Caribbean, which is largely dependent on one main source market, it appeared that Seychelles is not as dependent as the Caribbean on a single country (although approx. $70 \%$ of arrivals came from Europe, the tourists were from various countries - Italy, Great Britain, France, Germany). The article proposes the maximization of profits from tourism by focusing on the markets that generate the highest spending by visiting tourists (Germany, Switzerland, Great Britain, Italy). These markets also contribute to the largest increases in employment in tourism per tourist, and thus the biggest gains for the tourism economy of Seychelles.

\section{Reactions to crises and changes in the importance of tourism in the Seychelles economy}

Issues relating to the reaction of the tourism sector to crises have been highlighted by many researchers. The analysis of the significance of economic crises for the tourism sector has been undertaken by H.Y. Kim, M.H. Chen and S.S. Jang (2006, p. 931) and T. Wang (2009, p 75). During the global economic crisis, in many countries and dependent territories, the reduction in tourism revenues was greater than the reduction in the number of tourist arrivals (Nowakowska, 2011, p. 35). The value of global demand which was created by tourist traffic decreased by $12.5 \%$ in 2009 . This means that the share of the tourism economy in the global GDP decreased from $9.8 \%$ in 2008 to $9.5 \%$ in 2010 (Nowakowska, 2011). F.L. Chu (2008) analysed the impact on tourism of the financial crisis and the terrorist attacks of 11 September 2001. These were examples of crisis-type political and economic events affecting the tourism sector.

Research devoted to the response of the tourism sector on islands usually involve specific case studies. The impact of the economic crisis on tourism in Southern Cyprus was examined by F. Okumus and K. Karamustafa (2005). The analysis showed that tourism operators did not predict the consequences of the crisis for local tourism and did not undertake any remedial activities (Wang, 2009, p. 76 after Okumus, Karamustafa, 2005). The impact of the global economic crisis on Cyprus was also analysed by K. Podhorodecka (2016). The influence of natural disasters on tourism has been described in an article entitled 'Natural hazard and disaster tourism' by D. Rucińska and M. Lechowicz (2014).

Tourism in Seychelles began to develop early (in the mid-1970s) compared to other tropical island areas. In 1971, an international airport was opened, which resulted in a significant increase in the number of tourists. In the 1980s, the rate of growth in the number of tourists decreased due 
to the political problems in the area. The development of individual islands varied, and there was an interpenetration of the tourist and non-tourist spaces on the islands (Jędrusik, 2002, p. 108; Jędrusik, 2005, p. 189). In 1983, Seychelles was visited by 60,000 tourists, and by 1990 , the number of tourists reached 100,000. Even the global economic crisis did not significantly reduce the growth rate of tourist arrivals to the islands. In 2007, Seychelles was visited by over 171,000 tourists, and in 2008 by 2,000 more. 2009 saw a decrease in the number of tourist arrivals for most countries. Meanwhile, Seychelles recorded a 3\% increase in 2009, to 178,000. In 2010, a significant increase of $7.3 \%$ was recorded. Over the period 2005-2015, the stable increase in the number of tourist arrivals continued.

There was no decrease in the number of arrivals of foreign tourists in connection with the global economic crisis (Figure 1). A fall in the number of foreign tourist arrivals was only recorded in 2002, and this was due to the worldwide tendency towards a decline in tourist traffic in connection with the terrorist attacks on the World Trade Center. Against the background of other island areas dependent on tourism (with a proportion of above 10\% of GDP coming from tourist spending), Seychelles coped extremely well during the global economic crisis.

It may be concluded that the tourism sector in Seychelles partially bypassed the global economic crisis, since most island territories recorded declines in the number of foreign tourist arrivals and tourism revenue during this period.

Among the 17 analysed small tourist islands (with an area of less than $30,000 \mathrm{~km}^{2}$ ), Seychelles ranked $4^{\text {th }}$ in terms of changes in tourist traffic during the global economic crisis. The largest increases in the number of tourists in the period 1984-2000 in Seychelles were registered in 1984 $(+15 \%), 1990(+27 \%)$ and $1993(+17 \%)$. Meanwhile, the largest decreases in this period occurred in $1986(-9 \%), 1991(-13 \%)$ and $1994(-5 \%)$. The largest increases in the period 2001-2015 were recorded in $2006(+12 \%), 2007(+13 \%), 2011(+10 \%)$ and $2015(+24 \%)$, while the largest decreases in this period occurred in $2001(-1 \%)$ and $2003(-4 \%)$. Figure 1 shows changes in the number of foreign tourist arrivals and one-day visitors, as well as changes in the value of gross domestic product in Seychelles.

The Seychelles economy experienced global economic crisis in 2008, when a GDP decline of $-1.9 \%$ was registered, and in 2009 , when the decline was $-1.1 \%$. This article examines the relationship between changes in the rate of foreign tourist arrivals and changes in GDP. The Spearman's rank correlation coefficient and the Kendall's tau between the above-mentioned variables in the period 1984-2015 were calculated. The Spearman's rank correlation coefficient was 0.516 and was statistically significant at the 0.01 level. Meanwhile, the Kendall's tau was 0.352 and was also statistically significant at the 0.01 level (Abdi, 2007, pp. 5-7).

In the case of the first correlation, this translates into the existence of a moderate positive relationship, and in the case of Kendall's tau, the existence of a discernible, but low, positive relationship (Ostasiewicz, Rusnak, Siedlecka, 1999, p. 276). Therefore, along with the changes in the number of tourist arrivals to Seychelles, there were similar changes in the rate of economic development of these islands. This confirms the importance of the tourism sector for the economy of Seychelles. However, when analysing changes in the amount of tourist spending in Seychelles with changes 
in the GDP in the period 1998-2015, a Kendall's tau of 0.229 is observed. The Spearman's correlation between these variables is 0.311 . Neither correlation is statistically significant. It should be noted that a relationship between changes in the number of tourists and changes in GDP is not recorded for all island territories. It does not occur in the case of Aruba, Saint Kitts and Nevis or the Bahamas, while in the case of Cyprus, Dominica, Saint Lucia, and Saint Vincent and the Grenadines, it is decidedly smaller.

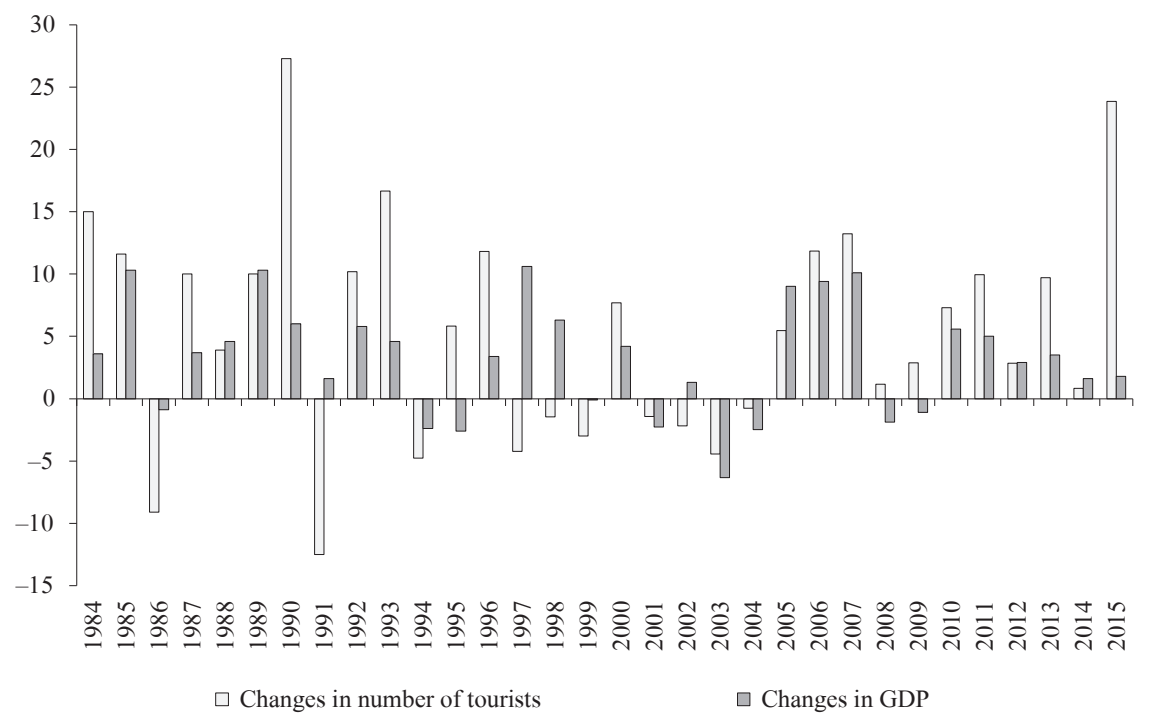

Figure 1. Changes in the number of foreign tourist arrivals and one-day visitors, and changes in the value of gross domestic product in Seychelles in the period 1984-2015 (\%)

Source: own study based on data from the UNWTO (www.unwto.org) and Compendium of Tourism Statistics, 1983-1987, 1994-1998, 1990-1994, 1999-2003, 1988-1992, 2003, 2005, 2009-2013, World Tourism Organization, Madrid, and based on data from the UNWTO database and the World Bank (www.worldbank.org).

Data on the share of tourism economy in generating GDP vary because of the different calculation methods used. When comparing spending by foreign tourists to the level of GDP in a given year, it can be stated that tourism in Seychelles in 2014 generated 31.8\% of the GDP (www.unwto.org). The latest WTTC methodology defines tourism industry as "industry closely related to tourism" (e.g. hotels and travel agencies), and the tourism economy more broadly as all products and services created for tourists (e.g. purchase of fuel, food). However, the tourism-induced effect also takes into account the purchasing power of people working in the local tourism sector. This means that the share of tourism industry in Seychelles in 2014 was 20\%, and the share of tourism economy in generating GDP was $48 \%$. Taking into account the induced effect, tourism economy in Seychelles generated $58 \%$ of GDP. 


\section{Changes of employment in tourism and changes in tourist spending in Seychelles}

In the period 2005-2008, a rapid increase was recorded in employment in the tourism sector in Seychelles, from 7,000 in 2005 up to 13,000 in 2008. In 2009, the tourism sector only partially made up for the losses connected with global economic crisis in terms of the tourism employment rate. Unfortunately, Seychelles has experienced a lasting decline in jobs in tourism, although number of tourists has returned to pre-crisis values. Figure 2 shows the level of employment in the tourism industry in the period 1988-2015. Initially, between 1988 and 2003, the number of employees in the tourism industry ranged from 4,000 to 6,000 people; this was followed by an increase, with the level reaching 7-8,000 people in 2004-2006, and 11-12,000 in 2008-2011.

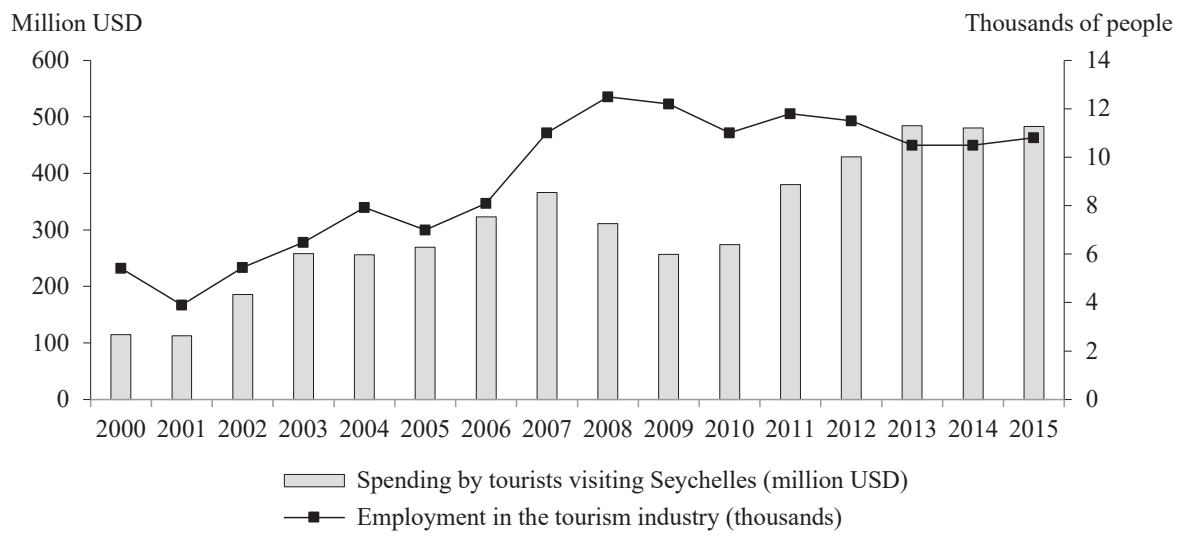

Figure 2. Employment in the tourism industry in the period 1988-2015 (thousands of people) and spending by foreign tourists and one-day visitors in Seychelles in 1997-2015 (million USD).

Source: developed on the basis of employment - 'Seychelles, Travel \& Tourism Forging Ahead', The 2004 Travel \& Tourism Economic Research, 2004, WTTC, Oxford; 'Travel \& Tourism Economic Impact 2015, Seychelles', 2015, 'World Travel \& Tourism Council', London, p. 3; spending - data for the period: 2000-2001 - 'Compendium of Tourism Statistics'. Data 1997-2001, 2003, UNWTO, Madrid, data for the period 2003-2007 - 'Compendium of Tourism Statistics'. Data 2003-2007, 2009, UNWTO, Madrid, data for the period 2008-2015 - UNWTO database.

Figure 2 also presents the level of spending by foreign tourists and one-day visitors in Seychelles in the period 1997-2015. Fluctuations in spending are clearly observable. The pre-crisis spending level was only reached in 2011. However, comparing this statistical data to the results of other island states, a positive trend can be observed. The decline in tourist spending in 2009 amounted to $18 \%$, and in 2010 an increase of just $6 \%$ was registered.

It should be noted that tourists arriving in Seychelles stay for a relatively long time (average length of stay is 10 days) and spend considerable sums of money (around USD 1,961 per person) (Seychelles..., 2013, p. 3). This means that the economic significance of tourism is decidedly higher than in other island areas. For comparison, tourist spending on the islands of the Caribbean are far 
lower (Grenada: USD 243 per tourist, Dominica: USD 127 per tourist, Antigua and Barbuda: USD 323 per tourist, Saint Kitts and Nevis: USD 151 per tourist, and Anguilla: USD 143 per tourist ${ }^{1}$ ).

\section{Managing the development of tourism in Seychelles}

Tourist administration of Seychelles ${ }^{2}$ has prioritized the development of the tourism services market based on high-standard services. Actions have been planned to ensure the sustainable development of tourism in economic and social terms (Tourism Focus Group Vision 21 Secretariat..., 2003, p. 2).

A strategic document of the Seychelles tourism sector forms a part of the 'Seychelles strategy for 2017', which was prepared by the Government of Seychelles. The strategy includes basic guidelines for the organization of tourism in Seychelles, as well as strategic objectives, a diagnosis and a strategic analysis. The objectives set out in the document aim to increase the number of foreign tourists and to increase their spending. The implementation of the strategic premises focuses on improving the quality of tourist products and increasing the participation of the local community in tourism services (Seychelles..., 2010, pp. 11-16). According to the data presented in the document, until 2005, the tourism sector generated 50\% of exports and $20 \%$ of Seychelles' GDP, and employed around 7,300 people. However, if the entire tourism economy is taken into account in the analysis, it is estimated that $40 \%$ of jobs were generated by the tourism sector. In addition to an increase in foreign tourist trips, the average spending of foreign tourists also registered an increase (of 6\% annually in the period 2001-2005). The number of beds, in particular in 4-star and 5-star facilities, also increased (Seychelles..., 2010). The utilization rate of the accommodation base in Seychelles was $46 \%$. Unfortunately, there is a noticeable occurrence on the islands of the transfer of profits from tourism abroad, also known as 'tourism leakage'. This is due to the fact that the hotels mostly belong to foreign investors (Seychelles..., 2010). Monetary transfers are also made by people working in the tourism sector (economic migrants send money to their families in their home countries). Unfortunately, local employees in the tourism sector earn about $10 \%$ below the average national earnings. Over $80 \%$ of tourists visiting Seychelles come from Europe, which results in a high dependence of tourist traffic on this part of the world, although the diversity of arrivals within the European market is very high.

Strategic document proposes the creation of 'tourism excellence' training centres in the form of hotel schools, which should contribute to improving the competence of the local workforce. This is to enable local population to take managerial positions, which should translate into a reduction in the financial transfers being made from tourism outside the islands (Seychelles..., 2010). An important goal in the strategic document is the improvement of the utilization of accommodation to the level of $60 \%$ in the 4-star and 5-star hotel segment (Seychelles..., 2010, p. 15). Additionally,

\footnotetext{
${ }^{1}$ Data for 2009.

${ }^{2}$ Tourist administration is understood as the central administration or National Tourist Administration (NTA), which in the case of Seychelles is the Seychelles Ministry of Tourism and Culture and the National Tourism Organization (NTO) - Seychelles Tourism Board.
} 
the Seychelles will be promoted in Eastern Europe, India, China and Arab countries. A decision was made to expand the seaport infrastructure in order to allow the arrival of major cruise ships (Seychelles..., 2010, p. 15).

High diversity of markets in inbound tourism could be another reason why Seychelles responded well to the global economic crisis in terms of inbound tourism. In order to examine the level of diversification of markets in inbound tourism, the study uses a modified version of E. Amemiya's economic base diversification index. The index has previously been used in economic geography to measure the degree of diversification from the point of view of employment (Gwosdz, Ciechowski, Micek, 2010, after Jerczyński, 1973). The index has a value between 0 and 1 (i.e. $<0,1>$ ), where 0 is a fully diversified structure of inbound tourism, and 1 is total domination by a single market ${ }^{3}$. The number of foreign tourists arriving from the main markets was analysed. The division proposed by E. Kubejko-Polańska $(2013)^{4}$ was used to interpret the index. The inbound tourism diversity index for Seychelles was 7.1.

The results show that Seychelles had the most diversified markets in inbound tourism, along with the Maldives, which was the only example among the 17 island territories to have a better index with a significant proportion of GDP generated by tourism. However, a much lower level of diversification of inbound tourism markets (and hence, higher index values) is recorded for the Caribbean islands.

\section{Results of the expert interview on tourism management in island areas during global economic crisis}

An expert interview was granted by a representative of the Ministry of Tourism of Seychelles. In the interview, it was highlighted that the documents currently in force in Seychelles are 'Strategy of Tourism 2017', 'Seychelles Sustainable Development Strategy' and 'Seychelles 2012-2020 Tourism Master Plan'. At the time of the global economic crisis, the islands had two strategic documents: 'Vision 2001-2010' and 'Seychelles Strategy 2017'. Seychelles created marketing campaigns during the crisis under the name 'Affordable Seychelles Marketing Campaign' and 'Market Source Over Satisfaction Supported by Air Access'. The Ministry indicated that there was an increase in funding for the promotion of tourism during global economic crisis (in 2009: 30 million rupees, in 2010: 35 million rupees, in 2011: 38 million rupees). There was no special team working on counteracting the effects of the global economic crisis in tourism. No special expert opinions were commissioned on the subject. Against the background of other expert interviews conducted on other islands (Cyprus, Malta, Dominica, Mauritius), it can be concluded that the activities carried out by the Seychelles tourist administration were satisfactory. Other island areas, such as Malta, implemented many more activities during the crisis. In Malta, a special 'Crisis Committee' team was created to counteract the effects of the global economic crisis in tourism, and a special marketing campaign for inbound tourism was also prepared. In the case of other islands (Mauritius,

\footnotetext{
${ }^{3}$ For better readability, the index has been multiplied by 100 .

${ }^{4}$ The index has been multiplied by 100 (value below 15 - high degree of diversification, from 15 to 30 - medium, from 30 to 60 - low, 60 or above - very low).
} 
Cyprus, Dominica) from which responses were obtained, it can be noted that their activities were carried out on a smaller scale than in Seychelles. In Mauritius, special measures were taken to minimize losses related to the crisis. At that time, a special team was mobilized to implement a programme called the 'Economic Restructuring Competitiveness Programme'. The tasks of the special team were to develop recovery plans for tourism businesses which allowed them to survive on the market. In addition, the team was tasked with designing special financial instruments, such as the 'Leasing Equipment Modernization Scheme', in order to purchase new technological solutions and equipment for companies. In Cyprus, meanwhile, no special team was created to limit the effects of the crisis in the tourism sector; no special expertise was commissioned on this subject, nor was there any specific campaign to counteract the decline in inbound tourism. Likewise, no team was established in Dominica to counteract global economic crisis; no special expertise was commissioned in connection with the crisis, nor were there any special promotional campaigns to counteract the recession on the tourism market.

\section{Conclusions}

Seychelles is an island area which coped decidedly well with the problems of the downturn in the tourism services market caused by global economic crisis. The islands have unique qualities and constitute an exclusive destination for tourist visits that did not suffer during the global economic crisis. Seychelles saw a smaller decline in visits from wealthy tourists from Western Europe than other similar areas. The islands engaged in advertising and continued to acquire customers on new markets. They are well positioned in terms of market diversity, meaning that they are not dependent on tourists from a single country. The diversification index shows a very high diversification of inbound tourism markets for Seychelles. Against the background of other tourist island regions, these islands ranked the best in terms of this index, which may also have led to their good response to the downturn in the tourist services market.

Positive results for this area may have been a consequence of the persistent fashion for leisure trips to exclusive island areas. Therefore, the hypothesis regarding the decline in tourist traffic, tourist spending and employment in tourism is only partially confirmed. Only a decline in the level of tourist spending and a permanent trend of reduced employment in the tourism sector were recorded. Seychelles did not share the fate of other island areas which fell into a long-term recession in inbound tourism after the global economic crisis, such as Saint Vincent and the Grenadines, Antigua and Barbuda, Anguilla, Dominica, and the British Virgin Islands. The global economic crisis certainly did not result in reduced tourist traffic to Seychelles.

The correlation between changes in tourist traffic and changes in GDP was moderately positive: the Spearman's rank correlation coefficient was 0.516 and was statistically significant. Meanwhile, the Kendall's tau coefficient was 0.352 , indicating a discernible, but low, positive relationship (this coefficient was also statistically significant). Therefore, the hypothesis regarding the relationship between changes in tourist traffic and changes in GDP can be considered as partially confirmed. 
Tourism was managed in Seychelles mainly through the implementation of a range of marketing activities. In addition, a tourism development strategy was implemented in Seychelles with a series of activities aimed at maximizing tourism profits for the benefit of the local community. Seychelles is an island area which has operated an effective tourism policy. In connection with the above, the third hypothesis concerning the implementation of effective actions during the global economic crisis can be considered as confirmed. Data relating in particular to changes in the volume of tourist traffic confirm that this is a tourist destination which has effectively coped with global economic crisis.

\section{Summary}

Seychelles is an archipelago which began to develop tourism intensively from the 1970s. Competition among island territories is very high and Seychelles competes with Mauritius and Reunion at close range, and with the Maldives at a greater distance. The aim of this article is to answer the questions: to what extent does the economy of Seychelles depend on the tourism sector, and is there a correlation between changes in foreign tourist arrivals and changes in the GDP of Seychelles? Another aim of the article is to assess whether the tourism economy of Seychelles reacted to the global economic crisis. The final aim of the article is to assess how tourism is managed, especially in crisis situations. The methods used in the article are: analysis of the literature, statistical analysis, the Kendall's tau and Spearman's rank correlation coefficients, and an expert interview.

\section{Referencess}

Archer, B. (1995). Importance of tourism for the economy of Bermuda. Annals of Tourism Research, 4 (22), 918-930.

Archer, B., Fletcher, J. (1996). The economic impact of tourism in the Seychelles. Annals of Tourism Research, 1 (23), $32-47$.

Armstrong, H.W., Read, R. (2000). Comparing the Economic Performance of Dependent Territories and Sovereign MicroStates. Economic Development and Cultural Change, 48, 285-306.

Balaguer, J., Cantavella-Jorda, M. (2002). Tourism as a long run economic growth factor. The Spanish case. Applied Economy, 34, 877-884.

Bertram, G., Poirine, B. (2007). Island Political Economy. In: G. Baldacchino (ed.), A World of Islands: An Island Studies Reader (pp. 332-378). Canada-Malta: Institute of Island Studies and Agenda Academic.

Brigulgio, L. (1995). Small Island Developing States and Their Economic Vulnerabilities. "World Development", Elsevier Science Ltd., Great Britain, 1615-1632.

Chu, F.L. (2008). A fractionally integrated autoregressive moving average approach to forecasting tourism demand. Tourism Management, 1 (29), 79-88.

Compendium of Tourism Statistics (1983-1987, 1985). Madrid: World Tourism Organization.

Compendium of Tourism Statistics (1988-1992, 1990). Madrid: World Tourism Organization.

Compendium of Tourism Statistics (1990-1994, 1992). Madrid: World Tourism Organization.

Compendium of Tourism Statistics (1994-1998, 1996). Madrid: World Tourism Organization.

Compendium of Tourism Statistics (1999-2003, 2001). Madrid: World Tourism Organization.

Compendium of Tourism Statistics (2009-2013, 2011). Madrid: World Tourism Organization.

Gwosdz, K., Ciechowski, M., Micek, G. (no year). Ekonomiczne podstawy funkcjonowania i rozwoju gospodarki miast. 
Jędrusik, M. (2002). Strategie i bariery rozwoju państw i terytoriów wyspiarskich na Oceanie Indyjskim. "Afryka, Azja, Ameryka Łacińska”. Warszawa: Wydział Geografii i Studiów Regionalnych UW.

Jędrusik, M. (2005). Zasoby oceanów jako potencjał rozwojowy wysp tropikalnych. Czasopismo Geograficzne, 1-2 (76), $3-18$.

Jędrusik, M. (2014). The elusive sustainable development of small tropical islands. Miscellanea Geographica, 3 (18), 26-30.

Jerczyński, M. (1973). Zagadnienia specjalizacji bazy ekonomicznej większych miast w Polsce. Studia nad struktura funkcjonala miast. Prace Geograficzne IG PAN, 97, 74-83.

Kim, H.Y., Chen, M.H., Jang, S.S. (2006). Tourism expansion and economic development: The case of Taiwan. Tourism Management, 5, 925-933.

Kubejko-Polańska, E. (no year). Wielkość, struktura oraz stopień dywersyfikacji bazy ekonomicznej matych miast monofunkcyjnych województwa podkarpackiego. Państwowa Wyższa Szkoła Techniczno-Ekonomiczna im. ks. B. Markiewicza w Jarosławiu.

McElroy, J.L., Parry, C.E. (2010). The characteristics of small island tourist economies. Tourism and Hospitality Research, $10,315-328$.

Mydel, R., Groch, J. (1998). Popularna Encyklopedia Powszechna, Afryka. Kraków: Grupa Wydawnicza Bertelsmann, Oficyna Wydawnicza Fogra.

Nowakowska, A. (2011). Problemy i konflikty rozwoju turystyki. In: A. Gotowt-Jeziorska, K. Łopaciński (eds.), Turystyka w Polsce w okresie kryzysu. Warszawa: Polskie Stowarzyszenie Turystyki.

Okumus, F., Karamustafa, K. (2005). Impact of an Economic Crisis. Evidence from Turkey. Annals of Tourism Research, 4 (32), 942-961.

Okumus, F., Altinay, M., Arasli, H. (2005). The impact of Turkey's economic crisis of February 2001 on the tourism industry in Northern Cyprus. Tourism Management, 26, 95-104.

Ostasiewicz, S., Rusnak, Z., Siedlecka, U. (1999). Statystyka. Elementy teorii i zadania. Wrocław: Wydawnictwo Akademii Ekonomicznej we Wrocławiu.

Podhorodecka, K. (2016). The impact of the global economic crisis on tourism in Cyprus. Annals of Marketing \& Economics", 1 (2), 99-110.

Podhorodecka, K. (2014). Impact of tourist and one-day visitor arrivals on economic growth. Case study of the Cayman Islands. Miscelanea Geographica, 3 (18), 16-25.

Rucińskia, D., Lechowicz, M. (2014). Natural hazard and disaster tourism. Miscellanea Geographica. Regional Studies on Development, 1 (18).

Seetanah, B. (2011). Assessing the dynamic economic impact of tourism for island economies. Annals of Tourism Research, 1 (38), 291-308.

Seychelles, Travel \& Tourism Forging Ahead (2004). The 2004 Travel \& Tourism Economic Research, WTTC, Oxford.

Seychelles. Tourism Sector Review: Sustaining growth in a successful tourism destination (2013). The World Bank Group.

Seychelles' strategy for 2017 (2010). Government of Seychelles (Published on 29 April 2010).

Shareef, R., McAleer, M. (2005). Modeling International Tourism Demand and Volatility in Small Island Tourism Economies. International Journal of Tourism Research, 7, 313-333.

Smith, S.L.J. (2000). Measurement of Tourism's Economic Impacts. Annals of Tourism Research, 2 (27).

Sugiyarto, G., Blake, A., Sinclair, M.T. (2003). Tourism and globalization. Economic Impact in Indonesia. Annals of Tourism Research, 3 (30), 683-701.

Tourism Focus Group Vision 21 Secretariat, Thematic working group on ecotourism, Towards an ecotourism strategy for the $21^{\text {st }}$ century (2003). Ministry of Tourism and Transport of Seychelles.

Tourism in Small Island Developing States (SIDS). Building a more sustainable future for the people of Islands (2014). Madrid: UNWTO.

Wagner, J.E. (1997). Estimating the economic impact of tourism. Annals of Tourism Research, 3 (24), 592-608.

Wang, T. (2009). The impact of crisis events and macroeconomic activity on Taiwan's international inbound tourism demands. Tourism Management, 30, 75-82. 
Wang, T. (2009). The impact of crisis events and macroeconomic activity on Taiwan's international inbound tourism demands. Tourism Management, 30, 75-82.

Wites, T. (2009). Peripherality of the Kuril Islands - a Development Barrier or a Development Factor? Asia and Pacific Studies, 6, 81-95.

www.cia.gov/library/publications/the-world-factbook/CIA - The World Factbook

www.unwto.org - UNWTO

\section{EKONOMICZNE ZNACZENIE SEKTORA TURYSTYCZNEGO NA SESZELACH W OBLICZU ŚWIATOWEGO KRYZYSU GOSPODARCZEGO}

SŁOWA KLUCZOWE

STRESZCZENIE
Seszele, gospodarka turystyczna, wyspy tropikalne, kryzys w turystyce

Administracja turystyczna Seszeli już od lat 70. XX w. zaczęła intensywnie rozwijać turystykę na obszarze archipelagu. W ostatnim czasie dokonywano wiele dużych inwestycji w rozwój sektora turystycznego. Jednakże zjawiska kryzysowe takie jak światowy kryzys gospodarczy mogły przyczynić się do spowolnienia rozwoju tego sektora. Celem niniejszego artykułu jest uzyskanie odpowiedzi na pytanie: w jakim stopniu gospodarka Seszeli jest uzależniona od sektora turystycznego i czy istnieje zależność pomiędzy zmianami PKB a zmianami w ruchu turystycznym? Celem artykułu jest również sprawdzenie w jaki sposób gospodarka turystyczna Seszeli zareagowała na zjawisko kryzysowe w turystyce jakim był ostatni światowy kryzys gospodarczy? Ostatnim celem jest zbadanie jak gospodarka turystyczna Seszeli była zarządzana w trakcie światowego kryzysu gospodarczego? Metody badawcze zastosowane w artykule to: analiza danych statystycznych, metoda korelacji Tau Kendalla i Spearmana, analiza literatury oraz wywiad ekspercki. 